\title{
Pedagogical Education Practices in Communication Sciences and Disorders PhD Programs: A Pilot Study
}

\author{
Laura SMITH-OLINDE \\ Univ. of Arkansas for Medical Sciences, Iso@uams.edu \\ Stanley K. Ellis \\ University of Arkansas for Medical Sciences, skellis@uams.edu \\ DOI: doi.org/10.30707/TLCSD2.1Smith-Olinde
}

Follow this and additional works at: https://ir.library.illinoisstate.edu/tlcsd

Part of the Communication Sciences and Disorders Commons

\author{
Recommended Citation \\ SMITH-OLINDE, Laura and Ellis, Stanley K. (2018) "Pedagogical Education Practices in Communication \\ Sciences and Disorders PhD Programs: A Pilot Study," Teaching and Learning in Communication Sciences \\ \& Disorders: Vol. 2: Iss. 1, Article 5. \\ DOI: doi.org/10.30707/TLCSD2.1Smith-Olinde \\ Available at: https://ir.library.illinoisstate.edu/tlcsd/vol2/iss1/5
}

This Scholarship of Teaching and Learning Research is brought to you for free and open access by ISU ReD: Research and eData. It has been accepted for inclusion in Teaching and Learning in Communication Sciences \& Disorders by an authorized editor of ISU ReD: Research and eData. For more information, please contact ISUReD@ilstu.edu. 


\title{
Pedagogical Education Practices in Communication Sciences and Disorders PhD Programs: A Pilot Study
}

\author{
Abstract \\ The purpose of this study was two-fold: (1) to ascertain how research doctoral programs in \\ Communication Sciences and Disorders (CSD) characterize their own efforts to educate research \\ doctoral students about teaching at the college/university level; and (2) whether and how programs \\ introduce the "scholarship of teaching and learning" (SoTL) to PhD students. PhD program directors \\ $(\mathrm{N}=69)$ were emailed a survey for descriptions of university teaching instruction and SoTL activities, with \\ a $27.5 \%$ return rate $(n=19)$. Quantitative and qualitative analyses were used. Identified themes included, \\ "course or seminar", "experiential" and "required". One hundred per cent of respondents offer teaching \\ experiences and $58 \%$ require student participation. Sixty-three per cent offer a teaching course while $42 \%$ \\ require the course. It is unclear from the current data whether CSD PhD students are exposed to SoTL. \\ Given the robust, cross-disciplinary literature on teaching and learning, the time may be right for a \\ discussion on including teaching education and SoTL in CSD PhD programs.
}

\section{Keywords}

doctoral education, audiology, speech-language pathology, pedagogy, teaching assistants, scholarship of teaching and learning, preparing future faculty

\section{Cover Page Footnote}

End Notes 1 By September 30, 2017, NSF will fund at least three summer institutes and 75 supplements to existing awards to provide STEM doctoral students with opportunities to expand their knowledge and skills to prepare for a range of careers. 2 Biological Sciences; Computer and Information Science and Engineering; Education and Human Resources; Engineering; Geosciences; Mathematical and Physical Sciences; Social, Behavioral \& Economic Sciences 3 At the time the survey was distributed the Carnegie Foundation was using the 2010 system; given that schema has been updated, the information from Question 3 in the survey is not included in this report. 


\section{Introduction}

History of Ph.D. Pedagogy Education. The need to train graduate students to teach has long been recognized in research doctoral programs. As early as 1930, Gray (as cited in Ewens, 1977) and Laing (as cited in Nyquist, Abbott, \& Wulff, 1989) pointed out issues such as lack of explicit teaching training in $\mathrm{PhD}$ programs, and the need for mentored teaching experiences by new teachers. In the 1940s-1960s faculty described programs to introduce new teaching assistants (TAs) to issues related to teaching and teaching strategies. Dunkel (1958) provided an update on a 10-year-old University of Chicago program to train future faculty; the program consisted of mentored teaching and weekly seminars. Lippincott (1959) described a program for orienting new chemistry TAs to teaching. This program was composed of mandatory, non-credit discussions on pedagogy and laboratory topics, followed by mentored teaching of labs. Costin (1968) evaluated a graduate course designed to ready students as TAs and as faculty. The course content included developing objectives, evaluating whether objectives are met, ethics, and other topics. Interestingly, Costin also mentioned that research problems in teaching psychology were included in this course, i.e., the scholarship of teaching and learning (SoTL), in modern parlance. During the 1970s, research in this area began to include effectiveness measures of graduate teacher training programs (e.g., Carroll, 1977).

In the last 30-40 years, doctoral programs across disciplines have, at varying rates, incorporated formalized courses on the science of teaching and learning into research doctoral education, complementing the long-used method of mentored teaching. Are such courses really necessary? While in the past many faculty and students viewed teaching as an activity that can be picked up once hired, there is now a robust literature on teaching and learning that has been developed by faculty from many disciplines. Derek Bok, former president of Harvard University, wrote in 2013, "In short, pedagogy has become a much more complicated process that has evolved from an art that one can acquire by oneself to a subject requiring formal preparation" (p. 3).

The Scholarship of Teaching and Learning versus Scholarly Teaching. The Council of Academic Programs in Communication Sciences and Disorders (CAPCSD) issued a position statement (Friberg, Ginsberg, Cardinale-Dudding, Quach, \& Smith-Olinde, 2014) on SoTL with this definition: "The scholarship of teaching and learning is defined as the combination of three components: rigorous study of teaching and/or learning, peer review of these studies, and public dissemination of findings to advance pedagogical practice”. Ernest Boyer (1990), a PhD-level audiologist, originally put forward the model of various types of scholarship, intent on defining faculty work in a way that reflected the range of activities already existing in academe. These four types of scholarships were discovery, integration, application and teaching. The first three are most familiar and have been conducted by faculty for years: discovery adds to a discipline's knowledge base; integration connects information across disciplines; and application uses information to affect consequential problems practically. The final type of scholarship is that of teaching, later renamed "scholarship of teaching and learning." McKinney (2006) states that SoTL “...involves systematic study of teaching and/or learning and the public sharing and review of such work through presentations, performance, or publications" (p. 39). Boyer also contended that across all four types of scholarship one critical aspect was peer-reviewed dissemination of the findings. 
Scholarly teaching refers to an instructor who reads and applies relevant teaching literature, engages in teaching self-reflection, carries out observations on their own classes, and analyzes those data. Allen and Field (2005) contend that scholarly teaching also encompasses a person's contributions to curriculum as a whole. The endpoint is continually improving their own teaching and their students' learning. Although distinct concepts, the SoTL and scholarly teaching are sometimes interpreted as the same thing, as evidenced by several articles in which the distinctions between them is drawn (e.g., Allen \& Field, 2005; Potter \& Kustra, 2011; Spath, 2007).

Narrative Initiatives. There is evidence that a change in doctoral programs to include teaching instruction, with an aim toward scholarly teaching though not necessarily SoTL, is desired at the national level. One program is the partnership between the Council of Graduate Schools and the Association of American Colleges and Universities, who jointly developed the "Preparing Future Faculty" (PFF) program. Over the 10-year life of that initiative, 111 PFF programs were developed within the sciences and mathematics (Pruitt-Logan, Gaff, \& Jentoft, 2002) and 155 programs in the humanities and social sciences (Gaff, Pruitt-Logan, Sims, \& Denecke, 2002). A second and current undertaking is the National Science Foundation's (NSF) "Improving Graduate Student Preparedness for Entering the Workforce" (NSF, 2016). The target group is doctoral students in the science, technology, engineering and mathematics (STEM) disciplines. Evidence of the desired, wide-reaching impact of this project is clear from two facts: (1) the NSF has identified this program as an FY 16-17 Agency Priority Goal ${ }^{1}$ and (2) all seven NSF directorates ${ }^{2}$ are participating. As indicated by the title, this program aims to prepare doctoral students for any work setting, including academe.

A second source of evidence is seen within disciplines; psychology and business. The percentage of psychology research doctoral programs offering and requiring formal education on teaching instruction and practice has increased from 43\% (Meyers \& Prieto, 2000) to 65\% (Boysen, 2011). Research-based psychology $\mathrm{PhD}$ programs are not accredited, indicating this trend is not mandated by forces outside the academy, but is occurring within the discipline itself. A second occurrence within psychology is that Division 2 of the American Psychological Association, the Society for the Teaching of Psychology, promotes teaching excellence to enhance students' learning of psychology. The Society has established a quarterly journal, Teaching of Psychology, a twice-ayear newsletter, offers a number of peer-reviewed ebooks on teaching and learning and a repository for peer-reviewed teaching resources. Thus, faculty and students can disseminate successes and failures in teaching through the journal and newsletter, as well as add to their knowledge and teaching toolbox through those resources. In 2011 the Society commissioned a task force to document teaching criteria for model psychology teachers in undergraduate education. The task force published those criteria Richmond, Boysen, Gurung, Tazeau, Meyers, \& Sciutto (2014), providing a developmental tool for faculty and graduate programs to benchmark and improve their teaching skills.

Marx, Garcia, Butterfield, Kappen, \& Baldwin (2016) issued a call to business schools to begin a national conversation on how best to incorporate formal education about and preparation for teaching into their $\mathrm{PhD}$ curricula. Business schools, including $\mathrm{PhD}$ programs, are accredited by the Association to Advance Collegiate Schools of Business (AACSB, 2016). Standard 9, Curriculum Content, contains the following directive for doctoral education, "Preparation for faculty responsibilities in higher education, including but not limited to teaching" (p. 33). These 
two disciplines use different approaches to the organization and governance of their respective $\mathrm{PhD}$ programs, but they each have platforms for discussions on pedagogy inclusion in their research doctoral programs. Interestingly, all $\mathrm{PhD}$ students in both these disciplines, no matter their intended career path, receive pedagogy instruction. To that point Golde and Dore (2001) state, "Arguably, teaching skills will be important for all $\mathrm{PhD}$ recipients, regardless of what career they pursue. Synthesizing and explaining complex material is an asset in many settings" (p. 22).

Communication Sciences and Disorders. There has been concern in the field for several years about educating adequate numbers of individuals to replace CSD faculty (e.g., Wilcox, 1998; Oller, 2003). The American Speech-Language-Hearing Association's (ASHA) Academic Affairs Board (AAB) (2013) reports the number of PhD students entering programs has remained steady for a number of years; however, people retiring and leaving faculty ranks is enlarging the gap between the number of PhDs needed and the number available. To address this now-documented shortage of research PhDs, ASHA and CAPCSD joined together to investigate the issue and offer strategies. Reports from these joint efforts have been published periodically (Joint Ad Hoc Committee, 2002; 2008; ASHA, 2013). Since that first report, progress in several areas has been described, including: (1) improved collection of information about $\mathrm{PhD}$ programs: (2) research achievements, particularly of students, highlighted at annual conventions; (3) programs aimed at faculty retention; (4) new models for $\mathrm{PhD}$ education started (e.g., $\mathrm{MS}+\mathrm{PhD}$; $\mathrm{AuD}+\mathrm{PhD}$ ); and (5) the Council for Clinical Certification has added flexibility in completing the "clinical fellowship year", easing that process for some PhD students.

To identify various "PhD educational models that prepare future scientists in CSD" (p. 16), the $\mathrm{AAB}$ contacted $\mathrm{PhD}$ program coordinators with questions about recruitment, admissions, completion, attrition, coursework, teaching experiences, interdisciplinary experiences, program characteristics and challenges, and student outcomes (ASHA, 2016). The AAB members prepared and refined survey questions using an iterative process along with expert input. There were two guiding principles for data collection: (1) not collect data similar to extant program surveys (e.g., Higher Education Survey); and (2) gather qualitative data from each interviewee, resulting in a mixed methods study. These questions were then put to 73 of the $76 \mathrm{CSD} \mathrm{PhD}$ program directors/coordinators. Most of the questions in the ASHA survey are beyond the scope of the current study; the areas of overlap include: (1) do programs require a course on pedagogy; and (2) what teaching experiences are PhD students offered and are they required? The ASHA reported that about one-half of programs require a pedagogy course. Teaching experiences are more common with teaching assistantships "typical" in $86.5 \%$ of programs and "required" in $43.1 \%$, coteaching a course is typical in 59.7\% and required in 30.6\%, and independent teaching is typical in $60.9 \%$ and required in $26 \%$.

Purpose. Although there is overlap of questions between this study and the 2016 ASHA study, the current one was designed and data were collected prior to 2016. There are at least three items that distinguish the current study from the ASHA one: (1) number of respondents; (2) inclusion of a question about SoTL; and (3) comparison of survey responses to published program information. These differences are addressed in the discussion.

This study was undertaken as a pilot with a narrow focus on pedagogy knowledge dissemination and SoTL infusion in CSD PhD programs, thus the survey's brevity. The purpose of this pilot 
study was to ascertain how research doctoral programs in CSD characterize their own efforts to educate research doctoral students about teaching at the college/university level. A secondary purpose was to determine whether and how SoTL is introduced to research doctoral students.

\section{Method}

This mixed-methods, descriptive study was undertaken with research doctoral programs in the disciplines of CSD. The authors submitted a Human Subject Research Determination form to the university's Institutional Review Board. The study was determined to not be human subject research (IRB \#202364).

We emailed the survey to the doctoral program admissions contact for each CSD research doctoral program found on the ASHA website $(\mathrm{N}=69)$. The email explained the study; an attached Word document contained the survey and a response constituted consent. Respondents were asked to complete the survey if they were the appropriate person in that program, or alternatively to forward the survey to the correct person. Following the initial 69 emails sent, 11 surveys were returned, and a reminder email with the survey attached was emailed to the remaining 58 programs several days later. Following this second email, an additional 10 surveys were returned, for a return rate of $30.4 \%$. Of the 21 returned surveys, one indicated that the school no longer had a research doctoral program and a second survey was returned with no answers, leaving 19 surveys with usable responses for a final return rate of $27.5 \%$.

The 5-question survey (Appendix A) was developed to discover: (1) what content area(s) each program offers; (2) public or private school; (3) Carnegie classification ${ }^{3}$ of the university offering the program; (4) whether and how the program includes information on the scholarship of teaching and learning; and (5) what the program offers to prepare students for university teaching. We purposely did not define SOTL within the survey. This decision was made in order to elicit an unbiased response and determine how program directors defined that phrase.

Program mission statements and student handbooks were also accessed from departmental websites to ascertain program goals and the stated teaching-related content within the program. This last information was intended to validate the survey responses. For each item accessed on a departmental or university website, we looked for any information or disclaimer that the item we viewed may not be the most current. Although we saw no disclaimers, we cannot definitively state that the accessed information was current. We decided to use the posted information, however, because that was what was available to potential students. Descriptive statistics were used to look at the results for questions 1-2. Questions 4 and 5 were examined using descriptive quantitative and qualitative methods.

Both authors participated in analyzing the data. The first author's background is in audiology and hearing science, with 16.5 years spent as a faculty member in speech and hearing departments at three universities. The second author's background is in the discipline of higher education, with 16 years teaching experience at five higher education institutions, and expertise in conducting and analyzing qualitative research. A combination of the framework method (Gale, Heath, Cameron, Rashid, \& Redwood, 2013) and a phenomenological approach to analyze the qualitative data was 
used. Both authors individually read and coded the textual responses. A subsequent joint review of those analyses was undertaken and differences in coding were resolved.

\section{Results}

Demographics. Survey questions 1-3 provided demographic information with Table 1 listing the degree designators and self-identified school types of the responding programs. Four respondents indicated their research doctoral programs were in the disciplines of speech-language pathology/sciences, i.e., no hearing-related doctorate could be pursued. The remaining programs indicated students might pursue any area or interest within either CSD or speech-language-hearing sciences. The majority expressed on their website that programs of study would be crafted by the students under the advisement of a mentor and/or a faculty committee, suggesting that any area of interest within speech, language, voice, hearing, or balance was available to study. In addition, several said that related areas, for example neuroscience and public health, were supported by the program and university.

Table 1. Demographic information of the responding institutions

Program Areas/Degrees N N

Speech-Language Pathology only $\quad 4$

CSD or

Speech-Language-Hearing Sciences

Institution Type* $\quad$ N

Comprehensive/Regional 2

Research Intensive 10

Public 12

Private, Not-for-Profit 2

*Total $>19$ because respondents could mark more than one response

Most programs that participated in the study expected applicants would have an advanced degree in speech pathology or audiology; however, several indicated that backgrounds in other disciplines, for example linguistics, were welcome. It is most common that speech and hearing research doctoral programs exist within "R1" or "research intensive" universities and that was true among the respondents to this survey, although two respondents self-identify with the [old] Carnegie classification "Comprehensive/Regional"'3. Not surprisingly, the most common pairing under Institution Type was "public" and "research intensive."

Major Themes and Sub-Themes. All open-ended responses were included verbatim in Appendix B. The study revealed three major themes in strategies to prepare students in teaching and SoTL: "courses or seminars," "experiential" and "required" (Table 2). We defined "courses or seminars" as any formal gathering intended to convey information and skills on a particular topic, irrespective 
of program credit being awarded and whether it was within or external to the program. "Experiential" referred to students' active engagement in a teaching-related activity in undergraduate or graduate classes. Finally, "required" indicated that the information provided by a respondent clearly stated that students must have completed a particular activity to satisfy requirements for their program of study.

Table 2. Identified major themes and sub-themes

\begin{tabular}{lc}
\hline Themes and Sub-Themes & No. $(\%)$ \\
\hline \hline $\begin{array}{l}\text { Courses or Seminars* } \\
\text { Campus-wide event }\end{array}$ & $7(37)^{* *}$ \\
Within-program course or & $8(42)^{* *}$ \\
seminar & $7(37)$ \\
None mentioned & \\
Experiential* & $1(5)$ \\
Teach as Adjunct & $17(89)$ \\
Classroom Experience & $2(11)$ \\
Co-Teach & $14(74)$ \\
Mentored & $6(32)$ \\
Teaching Assistant & \\
Required & $8(42)$ \\
Course or Seminar & $11(58)$ \\
Experiential & *Total >19 because respondents could mark more than one response \\
**Three programs cited both internal and external courses or seminars
\end{tabular}

Courses or Seminars. Nearly $60 \%$ of respondents indicated there were one or more courses or seminar sessions offered within the program that focused on the principles of teaching and learning. Several universities offered campus-wide educational events available to everyone on campus that were based on these concepts. The term "series of seminars" was most often used by respondents to describe the offerings external to the program, which were offered by either a graduate school or a teaching and learning center. Of the seven positive responses for campuswide programs in Table 2, one program required their $\mathrm{PhD}$ students to attend the campus-wide Preparing Future Faculty series and did not offer courses within their curriculum, while the other six cite the external events as optional for PhD students and were in addition to a program offering. Seven programs made no mention of any course or seminar about teaching and learning being available to PhD students, either within the program or at the university.

Experiential Teaching. All respondents stated that some type of hands-on teaching experience was available to $\mathrm{PhD}$ students. A variety of experiences were mentioned - from being hired as adjunct faculty after completing a teaching practicum to the most common answer of "classroom experience." The range of activities making up "classroom experience" was wide, and about threequarters indicated a mentored teaching experience. Two programs recounted a two-step process: (semester 1) the student observes, grades papers, and might prepare one to two lectures for a class; (semester 2) the student is given responsibility for an entire course, usually with close supervision by a faculty member. A similar model had students being mentored while preparing a class one semester and teaching that course the next. An "apprenticeship", as explained by one respondent, 
might have the student responsible for a course or revising a course they already teach. "Coteaching" was done in only undergraduate courses in one response, but not specified in a second response. One program described that students participated in teaching rotations, exposing students to a variety of teaching styles. One program said industry-bound students may have priorities ahead of experiential teaching.

About one-third of the programs used the term "teaching assistant," but other phrases such as "teaching preceptorships," "teaching apprenticeship" and "teaching assignment" were used with a seemingly similar meaning. "Teaching assistant" appeared to designate a formal mechanism within the department; however, whether the other three terms indicated formal or informal mechanisms could not be discerned from the data. It was clear that not all PhD students had the opportunity to participate as formal teaching assistants. For example, one program indicated "some [students] get TA positions" (italics ours). In other cases respondents stated that a teaching assistantship must precede the student teaching a class on his/her own, and some indicated that the teaching assistantship might serve as a required mentored experience.

Required. We also wanted to determine whether the proffered courses/seminars and experiential activities were required for students, limiting inclusion in Table 2 to responses containing the word "required." Twelve of the 19 respondents said pedagogy courses or seminars existed for PhD students, with eight programs explicitly stating PhD students must take a course, seminar, or series of seminars. All respondents mentioned availability of experiential activities, and just under $60 \%$ required students to complete such an encounter (Table 2).

Triangulated Data. Information on departmental websites and in web-based graduate student handbooks was reviewed for indication of courses and hands-on teaching experiences that were offered and required (Table 3). These data were next compared to the surveys to determine if the responses match published information (Table 4).

Table 3. Published program information

\begin{tabular}{lccc}
\hline \multicolumn{1}{c}{ Teaching activity } & Stated Yes & Stated No & $\begin{array}{c}\text { No } \\
\text { Information } \\
\text { Seen }\end{array}$ \\
\hline \hline Experiential teaching offered & 14 & 0 & 5 \\
Experiential teaching required & 9 & 1 & 9 \\
Course offered & 8 & 0 & 11 \\
Course required & 9 & 0 & 10 \\
\hline \hline
\end{tabular}

Table 4. Comparison between published information and survey responses

\begin{tabular}{lccc}
\hline \multicolumn{1}{c}{ Teaching activity } & Website & Survey & $\begin{array}{c}\text { \% } \\
\text { Agreement }\end{array}$ \\
\hline \hline Experiential teaching offered & 14 & 19 & 74 \\
Experiential teaching required & 9 & 11 & 82 \\
Course offered & 8 & 12 & 67 \\
Course required & 9 & 8 & 89 \\
\hline \hline
\end{tabular}


The majority of discrepancies occurred because the published information did not appear to convey all opportunities and requirements of the programs. For example, five programs stated in the survey that experiential teaching opportunities were offered, yet that information was not apparent on their websites. Differences in that same direction existed for experiential teaching requirements and offering a course on teaching. The single discrepancy in the other direction was a required course on teaching. This difference might be explained easily, as the authors may have assigned that program a "no" in the survey if "required" was not present.

We found self-identified program goals for student outcomes (i.e., roles they are being prepared for) in mission statements, and most programs had more than one role intended for research doctoral students. All 19 respondents specifically listed "research", most often also including "independent research" capabilities; seven programs stated no other student role. Six of the programs indicated they also educated students to assume a faculty role in a higher education institution (i.e., "academia"); half of those programs required a course and half a teaching experience. Five schools specifically mentioned "teaching", with one requiring a course and three teaching experience. The program with both academia and teaching as goals required both a course and teaching experience.

Table 5. Program goals and program requirements for learning to teach

\begin{tabular}{cccc}
\hline $\begin{array}{c}\text { Stated Program } \\
\text { Goal }\end{array}$ & $\begin{array}{c}\text { Respondents } \\
\text { No. }(\%)\end{array}$ & $\begin{array}{c}\text { Experiential } \\
\text { Required } \\
\text { No. }(\%)\end{array}$ & $\begin{array}{c}\text { Course } \\
\text { Required } \\
\text { No. (\%) }\end{array}$ \\
\hline \hline All Programs & $19(100)$ & $11(58)$ & $8(42)$ \\
Academia & $6(32)$ & $3(50)$ & $3(50)$ \\
Teaching & $5(26)$ & $3(60)$ & $1(20)$ \\
Academia \& Teaching & $1(5)$ & $1(100)$ & $1(100)$ \\
Research & $7(37)$ & $4(57)$ & $2(29)$ \\
\hline \hline
\end{tabular}

Infusion of SoTL. In response to question 4 of the survey, "Does your program infuse SoTL into the $\mathrm{PhD} /$ Research Doctoral curriculum?" six programs indicated they did not, and the other 13 that they did. We followed up with "If yes, what do you do?" (Appendix B). Four programs indicated the same answer should be used for both the SoTL question and how students were trained to teach. Some respondents folded SoTL into existing seminars, others cited campus-wide programs in which this information was offered, and several identified experiential teaching and/or particular topics covered in courses (e.g., writing a syllabus) as their SoTL infusion practices.

\section{Discussion}

The study reported here was undertaken to describe how research doctoral programs in CSD characterized their own efforts to educate research doctoral students about teaching at the college/university level, and whether and how programs introduced SoTL to PhD students. 
Current results indicate that formalized courses or seminars, either inside or outside the program, existed in roughly $80 \%(n=19)$ of our sample with just over $40 \%$ requiring students to take such a course. All of the programs in our sample had teaching experiences available for their students, and just under $60 \%$ required students to participate in these experiences. By comparison, in the ASHA (2016) study, 49\% ( $n=73)$ required students to take a teaching course and "a few" others without a course required students to complete teaching workshops. In both the current and ASHA studies experiential teaching was more widespread than a course and could be categorized into teaching assistantship, co-teaching and independent teaching. The ASHA report indicated teaching assistantships were typical in $87 \%$ of programs, while $42 \%$ required one. Other typical experiential teaching reported was $60 \%$ co-teaching and $61 \%$ independently teaching, with $31 \%$ and $26 \%$, respectively, requiring those activities. The open response format of the current study revealed several different implementation models within those three categories. Thus, data from the current study, although a smaller sample than the ASHA one, both confirmed the ASHA findings and offered additional details about the programs. In aggregate, the themes and sub-themes identified in the current data indicate a trend toward offering both experiential teaching and formal coursework. The majority of CSD research doctoral programs recognize students' need for experiential teaching with a smaller subset of programs also requiring formal education on teaching and pedagogy.

Aside from the smaller sample size, there were at least two other aspects of the current study that distinguish it from the ASHA report. The first difference was our inclusion of a question about infusing SoTL into the research doctoral program, discussed below. The second lay in our accessing published program materials to validate the written responses. The findings of agreement between survey responses and published information in the current study were greater than $65 \%$ for all comparisons. Discrepancies were by and large that the published information did not include some of the opportunities and requirements of the programs. All 19 programs responding to our survey had research skills as a PhD student outcome goal and seven had no other. It would not be surprising if few of these programs required students to engage in either a teaching experience or pedagogy course. However, four of the seven (57\%) required experiential teaching and two $(28.5 \%)$ required a course. The other 12 programs listed research and academia, research and teaching, or all three, as student outcome goals. It would be reasonable to expect these programs to have student requirements which addressed these goals. Interestingly, about $60 \%$ of these programs required experiential teaching, similar to those with only research as a named outcome. Fifty per cent required at least one pedagogy course, almost double the research-only programs. At least one respondent indicated that a number of their PhD students planned to enter industry rather than higher education, the implication being that pedagogy instruction may not be a priority for these students versus those entering academia. Echoing Golde and Dore (2001), we make the following two points: (1) teaching occurs in every occupation, and although the setting and situation may change, the same evidence-based adult teaching principles apply, and (2) it is entirely possible that a CSD graduate who takes a job in industry will decide at a future date to enter a university as faculty.

We also point out that CSD faculty can pursue SoTL work in any institution, including in the absence of major external grants and at institutions that may not have internal funding for 
equipment-intensive discipline-based research. Students in all CSD disciplines and levels would benefit from faculty performing and disseminating SoTL work.

\section{Study Limitations and Future Work}

The authors made a deliberate decision to not define SoTL within the survey. The idea was to explore what responses people provided without biasing their perceptions towards any particular definition. In retrospect, not including the definition or asking respondents to supply a definition made the data difficult to interpret. The data may reveal respondents' understanding of the term, but did not necessarily inform about the program. Given that limitation of the study, no responses were consistent with the authors' operational definition of SoTL, systematic research of teaching and learning problems with subsequent peer reviewed dissemination. Future work on the introduction of SoTL to CSD PhD students will need to make clear the definition and perhaps include example activities.

The response rate of $27 \%$ is less than we had hoped, although we had a good distribution across the country and type of institution that was representative of all programs. The difference in response rate from the ASHA study is not difficult to understand. For the current study $\mathrm{PhD}$ program directors received an unsolicited request for information, whereas for the ASHA study members of an ASHA committee telephoned requesting information. Program coordinators likely are familiar with providing programmatic data to ASHA and are comfortable with use of those data. That same level of familiarity and comfort may not have been present with an unsolicited survey request.

We did not request specific program requirements, necessitating we interpret that aspect of the responses. Therefore, only if the respondent specifically included the idea of "required" did we count it as such. However, given the relative closeness of our results with those of ASHA, we think our approach resulted in reliable data. We did not survey students, graduates, and employers in this study, but have intentions to do so in the future. Clearly, student perceptions of any courses and experiential teaching could guide improvements, from the student viewpoint. For example, data from psychology graduates who became faculty members indicated increased teaching ability and clearer career aspirations than students who did not take a pedagogy course (Prentice-Dunn \& Rickard, 1994).

We characterize this work as a pilot study. Future work in this area might include:

- A more detailed account of programmatic approaches to teaching pedagogy and developing teaching and SoTL skills in graduate students;

- An examination of what topics are covered in courses and seminars about teaching;

- A survey of graduate students, alumni and faculty about graduate program teaching experiences, both didactic and experiential; and

- Determining whether there is there an association or correlation between the amount of education on teaching and alumni perception of higher education work readiness and selfassessment of job performance.

From the hiring institution perspective: 
- Is a teaching presentation required during the hiring process and what elements are important to observe during that presentation?

- Do interview requirements vary by type of hiring institution, for example a liberal arts college versus masters-granting versus $\mathrm{PhD}$-granting institution?

These are only potential examples of topics. Plainly, there are many reasonable questions to ask because there is little published literature about $\mathrm{PhD}$ programs in CSD.

\section{Pedagogy Inclusion?}

Should CSD programs ensure that pedagogical concepts and experiences are included in $\mathrm{PhD}$ education? Two pieces of evidence are germane. First, an examination of all CSD programs listed on the ASHA website (accessed 6-9-17) yielded 35 undergraduate-only programs, 211 with clinical preparation programs, most of which also have undergraduate programs, and $72 \mathrm{PhD}$ programs, most of which also have undergraduate and clinical preparation programs. These data suggest the bulk of $\mathrm{PhD}$ graduates from CSD programs who enter higher education will be employed in undergraduate-only or masters/clinical doctorate plus undergraduate programs. In these settings, it is quite likely that teaching and research expectations will differ from that of research-intensive universities, perhaps with a greater emphasis on teaching. Second, several groups have investigated the reasons why students and practitioners do and do not pursue a $\mathrm{PhD}$ in CSD (Madison, Guy \& Koch, 2004; Myotte, Hutchins, Cannizzaro \& Berlin, 2011; Davidson, Weismer, Alt, \& Hogan, 2013). Across these studies, and across all participant groups (practitioners, graduate students, faculty), an interest in teaching is high on the list of reasons to pursue a $\mathrm{PhD}$ and low on the list to not pursue one. Given the high interest level of current graduate students and practitioners, it is possible that including pedagogy instruction and making it clear pedagogy is part of the CSD PhD curriculum would encourage more individuals to pursue that degree. In turn, this could potentially address the impending research doctoral shortage. The fact that teaching, no matter the specific higher education setting, will be part of most faculty's assigned duties, combined with high interest in teaching as a reason to pursue a $\mathrm{PhD}$, suggest it is reasonable to educate doctoral students on how to teach. Outside CSD and academe, the national-level initiatives to prepare research doctoral students to teach seem to underscore the importance of including this information in research doctoral studies.

Is there be any benefit for doctoral students? Research suggests more attention given to teaching skills during research doctoral education would be well received by students. Golde and Dore's (2001) national, cross-discipline survey of graduate students reveal that while $81 \%$ of graduates are drawn to a research doctoral program by teaching, only $37 \%$ feel their programs adequately prepared them for the task. Feldon and colleagues (2011) compared research proposals of two groups of STEM graduate students. One group engaged in only research activities and the second group performed research and taught. Results indicated that the students who taught and performed research significantly improved over the year, compared to the only-research students, at designing experiments and developing testable hypotheses. Prentice-Dunn and Rickard (1994) compared performance of two groups of graduate students in psychology on the "Area Concentration Achievement Test" (ACAT), 240 multiple choice items in 12 psychology topics. The control and experimental groups of graduate students had about the same level of training, but the experimental group completed a supervised teaching experience that the control group did not. Results indicated 
no group pretest score differences on the ACAT. However, the experimental group scored statistically significantly better than the control group in some, though not all, areas on the posttest, suggesting teaching content may better help individuals retain that content. Thus, there is evidence that $\mathrm{PhD}$ students in CSD could receive benefit in both research skills and content retention if they engage in teaching as a student.

Based on the current study and the ASHA (2016) data, that a number of CSD PhD programs already include pedagogical information and/or teaching experiences, it may be time to add teaching pedagogy and SoTL to the discipline-wide $\mathrm{PhD}$ discussions already occurring. Richmond and colleagues' (2014) article describing an aspirational teaching criteria model could serve as a resource for such a conversation. DiPietro and Buddie (2013) point out that in the U.S. there is no overarching body that governs how graduate students are educated about teaching, and it is unlikely that a one-size-fits-all approach would work or is even desirable, given differences among programs and universities. However, such a discussion could prove fruitful with programs already incorporating those elements sharing what has and has not worked in their setting. Other sources could provide additional ideas; for example, Marx et al. (2016) suggested recruiting retired faculty to mentor students in teaching. McElroy and Prentice-Dunn (2005) surveyed students about the course elements that they viewed as helpful, which included peer observation, recording themselves throughout the semester with feedback from the instructor, and self-assessment, among others. In short, CSD programs could build on others' successes to provide their students relevant and helpful teaching knowledge and opportunities. The 2016 report disseminated by ASHA could serve as a baseline on pedagogical instruction in CSD research doctoral programs. ASHA and CAPCSD jointly sponsor an annual Higher Education Survey of all CSD programs (undergraduate, masters, clinical doctorates and research doctorates). Expanding that survey to include questions on formal pedagogy instruction and experiential teaching opportunities and requirements for research doctoral students would provide a way to track inclusion of these items across programs.

\section{References}

Association to Advance Collegiate Schools of Business International. (2016). Eligibility procedures and accreditation standards for business accreditation. AACSB International, Tampa, FL.

American Speech-Language-Hearing Association. (2013). Strategic plan to increase the student pipeline and workforce for PhD researchers and faculty researchers. American SpeechLanguage-Hearing Association, Rockville, MD. Retrieved from http://www.asha.org/uploadedFiles/Report-2013-AAB-PhD-Report-Strategic-Plan.pdf

American Speech-Language-Hearing Association. (2016). PhD programs in communication sciences and disorders: Innovative models and practices. American Speech-LanguageHearing Association, Rockville, MD. Retrieved from http://www.asha.org/uploadedFiles/2016-PhD-Programs-in-CSD-Report.pdf

Allen, M. N. \& Field, P. A. (2005). Scholarly teaching and scholarship of teaching: Noting the difference. International Journal of Nursing Education Scholarship, 2(1): 12.

Bok, D. (2013). We must prepare Ph.D. students for the complicated art of teaching. The Chronicle of Higher Education, 1-7.

Boyer, E. L. (1990). Scholarship reconsidered: Priorities of the professoriate. The Carnegie Foundation for the Advancement of Teaching. San Francisco, CA: Jossy-Bass. 
Boysen, G. A. (2011). The prevalence and predictors of teaching courses in doctoral psychology programs. Teaching of Psychology, 38(1), 49-52.

Carroll, J. G. (1977). Assessing the effectiveness of a training program for the university teaching assistants. Teaching of Psychology, 4(3): 135-137.

Costin, F. (1968). A graduate course in the teaching of psychology: Description and evaluation. Journal of Teaching Education, 19(4): 425-432.

Davidson, M. M., Weismer, W. E., Alt, M., \& Hogan, T. P. (2013). Survey on perspectives of pursuing a PhD in communication sciences and disorders. Contemporary Issues in Communication Sciences and Disorders, 40, 98-115.

DiPietro, M. \& Buddie, A. M. (2013). Graduate teacher training in the U.S.: Snapshots from the landscape. Revista de Docencia Universitaria, 11(3), 41-52.

Dunkel, H. B. (1958). Training College Teachers. The Journal of Higher Education, 29(1), 1-58.

Feldon, D. F., Peugh J., Timmerman, B. E., Maher, M. A., Hurst, M., Strickland, D., Gilmore, J. A., \& Stiegelmeyer, C. (2011). Graduate students' teaching experiences improve their methodological research skills. Science, 333(6045),1037-1039. doi: 10.1126/science.1204109

Ewens, B. (1977). Preparing Graduate Students to Teach: A Selected, Annotated Bibliography. Retrieved from http://files.eric.ed.gov/fulltext/ED139713.pdf.

Friberg J., Ginsberg S., Cardinale-Dudding C., Quach W., \& Smith-Olinde, L. (2014). Scholarship of teaching and learning position paper. Council on Academic Programs in Communication Sciences and Disorders. Retrieved from http://www.capcsd.org/academicclinicalresources/sotl-position-paper/

Gaff, J. G., Pruitt-Logan, A. S., Sims, L. B., \& Denecke, D. D. (2002). Preparing future faculty in the humanities and social sciences: A guide for change. Council of Graduate Schools and Association of American Colleges and Universities, Washington, D. C. Retrieved from http://www.preparing-faculty.org/PFFWeb.PFF4Manual.pdf.

Gale, N. K., Heath, G., Cameron, E., Rashid, S., \& Redwood, S. (2013). Using the framework method for the analysis of qualitative data in multi-disciplinary health research. BMC Medical Research Methodology, 13, 117-124. Retrieved from http://www.biomedcentral.com/1471-2288/13/117.

Golde, C. M. \& Dore, T. M. (2001). At cross purposes: What the experiences of today's doctoral students reveal about doctoral education. Pew Charitable Trusts, Philadelphia, PA. Retrieved from http://files.eric.ed.gov/fulltext/ED450628.pdf

Joint Ad Hoc Committee. (2002). Crisis in the discipline: A plan for reshaping our future. American Speech-Language-Hearing Association and Council of Academic Programs in Communication Sciences and Disorders. Retrieved from http://www.capcsd.org/wpcontent/uploads/2015/01/JointAdHocCmteFinalReport.pdf

Joint Ad Hoc Committee. (2008). Report of the joint ad hoc committee on $\mathrm{PhD}$ shortages in communication sciences and disorders. American Speech-Language-Hearing Association and Council of Academic Programs in Communication Sciences and Disorders. Retrieved from

http://www.asha.org/uploadedFiles/academic/reports/2008PhDAdHocComFullReport.pdf

Lippincott, W. T. (1959). Training teaching assistants for general chemistry. J. Chem. Educ, 36(2), 84.

Madison, C. L., Guy, B., \& Koch, M. (2004). Pursuit of the speech-language pathology doctorate: Who, why, why not. Contemporary Issues in Communication Sciences and Disorders, 31, 
191-199.

Marx, R. D., Garcia, J. E., Butterfield, D. A., Kappen, J. A., \& Baldwin, T. T. (2016). Isn't it time we did something about the lack of teaching preparation in business doctoral programs? Journal of Management Education, 40(5), 489-515.

McElroy, H. K. \& Prentice-Dunn, S. (2005). Graduate students' perceptions of a teaching of psychology course. Teaching of Psychology, 32(2), 122-124.

McKinney, K. (2006). Attitudinal and structural factors contributing to challenges in the work of the scholarship of teaching and learning. New Directions for Institutional Research, 129 (Summer), 37-50.

Meyers, S. A. \& Prieto, L. R. (2000). Training in the teaching of psychology: What is done and examining the differences. Teaching of Psychology, 27(4), 258-261.

Myotte, T., Hutchins, T. L., Cannizzaro, M.S., \& Belin, G. (2011). Understanding why speechlanguage pathologists rarely pursue a $\mathrm{PhD}$ in communication sciences and disorders. Communication Disorders Quarterly, 33(1), 42-54.

National Science Foundation 16-067. (2016). Dear colleague letter: Improving graduate student preparedness for entering the workforce, opportunities for supplemental support. National Science Foundation. Retrieved from https://www.nsf.gov/pubs/2016/nsf16067/nsf16067.jsp

Nyquist, J. D., Abbott, R. D., \& Wulff, D. H. (1989). The Challenge of TA training in the 1990s. Teaching Assistant Training in the 1990s, ed. Nyquist, Abbott, and Wulff, New Directions for Teaching and Learning, 39: 15-22.

Oller, D. K. (2003). The PhD shortage in communication sciences and disorders. SIG 10 Perspectives on Issues in Higher Education, 6, 2-3. doi:10.1044/ihe6.1.2

Potter, M. K. \& Kustra, E. D. H. (2011). The relationships between scholarly teaching and SoTL: Models, distinctions, and clarifications. International Journal for the Scholarship of Teaching and Learning, 5(1), Article 23.

Prentice-Dunn, S. \& Rickard, H. C. (1994). A follow-up note on graduate training in the teaching of introductory psychology. Teaching of Psychology, 21(2), 111-112.

Pruitt-Logan, A. S., Gaff, J. G., \& Jentoft, J. E. (2002). Preparing future faculty in the sciences and mathematics: A guide for change. Council of Graduate Schools and Association of American Colleges and Universities, Washington, D. C. Retrieved from http://www.preparing-faculty.org/PFFWeb.PFF3Manual.pdf.

Richmond, A. S., Boysen, G. A., Gurung, R. A., Tazeau, Y. N., Meyers, S. A., \& Sciutto, M. J. (2014). Aspirational model teaching criteria for psychology. Teaching of Psychology, 41(4), 281-295.

Spath, M. L. (2007). A need for clarity: Scholarship, scholarly teaching, and the scholarship of teaching and learning. Nursing Education Perspectives, 28(5), 235-236.

Wilcox, K. A. (1998). Replacing the professoriate: Perspectives from a doctoral program. Council of Academic Programs in Communication Sciences and Disorders. Retrieved from http://capcsd.org/proceedings/1998/ReplacingProfessorate.htm

\section{Notes}

${ }^{1}$ By September 30, 2017, NSF will fund at least three summer institutes and 75 supplements to existing awards to provide STEM doctoral students with opportunities to expand their knowledge and skills to prepare for a range of careers. 
${ }^{2}$ Biological Sciences; Computer and Information Science and Engineering; Education and Human Resources; Engineering; Geosciences; Mathematical and Physical Sciences; Social, Behavioral \& Economic Sciences

${ }^{3}$ At the time the survey was distributed the Carnegie Foundation was using the 2010 system; given that schema has been updated, the information from Question 3 in the survey is not included in this report. 


\section{Appendix A \\ Survey}

1. In which area(s) do you offer research doctoral degrees? Check all that apply.

$\square$ Speech-Language Pathology

Audiology

$\square$ Speech-Language-Hearing Science

$\square$ "Communication Sciences \& Disorders," i.e., students may choose area of study

2. What type of university is your institution? Check all that apply.

$\square$ Private, Not-for-profit $\square$ Research Intensive

$\square$ Private, For-profit $\quad \square$ Comprehensive/Regional

$\square$ Public

3. Carnegie Classification (Optional)

$\square$ RU/VH - Research University (very high research activity)

$\square$ RU/H-Research University (high research activity)

$\square$ DRU-Doctoral/Research University

$\square$ Other

4. Does your program infuse the scholarship of teaching and learning into the $\mathrm{PhD} / \mathrm{Research}$ Doctoral curriculum? $\square$ Yes $\square$ No

If yes, what do you do?

5. Please describe how your program prepares research doctoral students to teach at the college level. 


\section{Appendix B}

Survey Responses

\begin{tabular}{|c|c|c|}
\hline Program & $\begin{array}{l}\text { Does your program infuse the } \\
\text { scholarship of teaching and learning } \\
\text { into the PhD/Research Doctoral }\end{array}$ & $\begin{array}{l}\text { Please describe how your program } \\
\text { prepares research doctoral students to } \\
\text { teach at the college level. }\end{array}$ \\
\hline 1 & \begin{tabular}{|l|} 
curriculum? \\
Individual mentoring during teaching
\end{tabular} & ester minimum of supervised \\
\hline 2 & $\begin{array}{l}\text { Doctoral seminar with relevant topics } \\
\text { such as syllabus development, teaching } \\
\text { portfolios, etc. }\end{array}$ & $\begin{array}{l}\text { Ongoing seminar with mix of dept led } \\
\text { and student suggested topics; we also try } \\
\text { to give each student one teaching } \\
\text { assignment; they are required to serve as } \\
\text { a TA for a class before being able to } \\
\text { teach on their own. }\end{array}$ \\
\hline 3 & TA-ship, & $\begin{array}{l}\text { Graduate College offers seminars; our } \\
\text { CSD funds students to TA, and } \\
\text { occasionally teach, courses with } \\
\text { mentorship }\end{array}$ \\
\hline 4 & $\begin{array}{l}\text { We offer a specific teaching seminar to } \\
\text { most Ph.D. students where we teach } \\
\text { about scholarship of teaching and } \\
\text { learning specifically to our students. If a } \\
\text { cohort is too small to take the seminar in } \\
\text { our department, the Ph.D. student/s take } \\
\text { a series of courses that are offered in our } \\
\text { Graduate School that specifically } \\
\text { address the scholarship of teaching and } \\
\text { learning. Students generally appreciate } \\
\text { the content of these courses a great deal. }\end{array}$ & $\begin{array}{l}\text { Our students attend a seminar on } \\
\text { teaching where they are taught about the } \\
\text { scholarship of teaching and learning. In } \\
\text { addition, Ph.D. students are required to } \\
\text { engage in teaching rotations with } \\
\text { faculty. This is not for pay, but for credit. } \\
\text { During these experiences the student is } \\
\text { responsible for multiple modules in a } \\
\text { course-developing the content, writing } \\
\text { examination questions, grading exams } \\
\text { and papers, etc. The faculty member } \\
\text { observes/records the student teaching } \\
\text { and offers feedback and mentorship. }\end{array}$ \\
\hline 5 & $\begin{array}{l}\text { There is a course they take called } \\
\text { Pedagogy, and there is an optional } \\
\text { certificate in teaching and learning } \\
\text { offered through the graduate school }\end{array}$ & $\begin{array}{l}\text { All students must complete a teaching } \\
\text { apprenticeship under the mentoring of } \\
\text { an individual who has been a valued } \\
\text { instructor. The scope of the } \\
\text { apprenticeship may vary from being } \\
\text { responsible for an entire course or } \\
\text { revising a course in which they are } \\
\text { already teaching. }\end{array}$ \\
\hline 6 & $\begin{array}{l}\text { Students take a course on teaching, and } \\
\text { they co-teach one lower level course } \\
\text { with one of the faculty members } \\
\end{array}$ & See answer on question 4 \\
\hline 7 & $\begin{array}{l}\text { Integrate these areas in existing doctoral } \\
\text { courses. }\end{array}$ & $\begin{array}{l}\text { All of our PhD students engage in } \\
\text { classroom teaching during their studies, }\end{array}$ \\
\hline
\end{tabular}




\begin{tabular}{|c|c|c|}
\hline & & $\begin{array}{l}\text { either at the UG or Graduate level or } \\
\text { both. }\end{array}$ \\
\hline 8 & $\begin{array}{l}\text { Our doctoral program in } \\
\text { Communication Sciences requires } \\
\text { students to participate in the Preparing } \\
\text { Future Faculty (PFF) program offered } \\
\text { through the Graduate School. The PFF } \\
\text { program is designed specifically to } \\
\text { prepare doctoral students to enter the } \\
\text { professoriate by providing an integrated } \\
\text { view of the roles of a professional in } \\
\text { academia. This is accomplished through } \\
\text { seminars on designing courses, teaching } \\
\text { techniques, and solving instructional } \\
\text { problems as well as hands-on instruction } \\
\text { in the uses of new technology for } \\
\text { teaching and research. }\end{array}$ & $\begin{array}{l}\text { In addition to the PFF program, doctoral } \\
\text { students participate in a departmental } \\
\text { teaching assistantship program. The } \\
\text { department also offers doctoral students } \\
\text { training in the area teaching through a } \\
\text { two part program. Students are assigned } \\
\text { as Teaching Assistants during the first } \\
\text { phase of training during which they } \\
\text { shadow a professor by observing in their } \\
\text { courses, assisting as lab assistants and } \\
\text { conducting tutoring sessions. During the } \\
\text { second phase of the program the student } \\
\text { is assigned to teach an undergraduate } \\
\text { level course with the faculty mentor } \\
\text { assisting them throughout the process } \\
\text { from selection of supplementary texts or } \\
\text { articles to assistance with designing the } \\
\text { first lecture. }\end{array}$ \\
\hline 9 & $\begin{array}{l}\text { All Ph.D. students are required to } \\
\text { complete a series of professional } \\
\text { seminars. One of these specifically } \\
\text { addresses the pedagogy of teaching with } \\
\text { practical applications e.g. designing } \\
\text { syllabi and course exams. Students must } \\
\text { also gain teaching experience in the form } \\
\text { of guest lectures, teaching assistantships, } \\
\text { and teaching preceptorships (not all } \\
\text { levels are required). }\end{array}$ & See above. [to the left] \\
\hline 10 & $\begin{array}{l}\text { Our...Ph.D. program promotes the } \\
\text { teacher/scholar model. Our students are } \\
\text { introduced to the theories of teaching } \\
\text { pedagogy early in their program and } \\
\text { throughout the remainder of their } \\
\text { doctoral work. All students take the } \\
\text { required teaching pedagogy and } \\
\text { teaching internship courses. Our } \\
\text { doctoral students have the experience of } \\
\text { taking responsibility for a course (with } \\
\text { supervision) and handling all aspects of } \\
\text { the teaching experience including } \\
\text { developing course content and designing } \\
\text { lectures and examinations and } \\
\text { presenting lectures. Additionally, many } \\
\text { of our students have the opportunity to }\end{array}$ & $\begin{array}{l}\text { Our program was designed using a } \\
\text { teacher/scholar model and all doctoral } \\
\text { students are required to take a teaching } \\
\text { pedagogy course and a teaching } \\
\text { internship as part of their Ph.D. program. } \\
\text { Our students get multiple teaching } \\
\text { experiences throughout their program } \\
\text { and the importance of teaching is } \\
\text { emphasized as one of the primary roles } \\
\text { of academic faculty as outlined above. }\end{array}$ \\
\hline
\end{tabular}




\begin{tabular}{|c|c|c|}
\hline & $\begin{array}{l}\text { take full responsibility for teaching } \\
\text { courses beyond the required teaching } \\
\text { internship. One doctoral student } \\
\text { volunteered to teach four different } \\
\text { courses while in the program. She saw } \\
\text { these four course preparations as an } \\
\text { advantage to her when looking for a } \\
\text { faculty position. Doctoral students also } \\
\text { get experience in clinical teaching by } \\
\text { taking the required supervision } \\
\text { internship course as part of their } \\
\text { program. Our students are also } \\
\text { encouraged to disseminate information } \\
\text { by making presentations at state and } \\
\text { national conferences, which represents } \\
\text { another type of teaching experience }\end{array}$ & \\
\hline 11 & $\begin{array}{l}\text { We require a Teaching and Professional } \\
\text { Development course and mentored } \\
\text { teaching assistantships. The first year } \\
\text { students prepare } 2 \text { lectures, attend class, } \\
\text { and help with grading. The second year, } \\
\text { they prepare } 4 \text { lectures, attend class, and } \\
\text { help with grading. Typically most go on } \\
\text { to co-teach a course with another faculty } \\
\text { member or doctoral student in their third } \\
\text { year. Some also participate in a } \\
\text { university-wide intensive summer } \\
\text { course on teaching. }\end{array}$ & Same as \#4 \\
\hline 12 & $\begin{array}{l}\text { Students are required to complete a one- } \\
\text { semester mentored teaching experience, } \\
\text { in addition to regular guest lectures in } \\
\text { undergraduate and graduate courses. } \\
\text { Students also may complete a } \\
\text { university-wide specialty certificate } \\
\text { program in teaching. }\end{array}$ & See answer to 4. \\
\hline 13 & No response & $\begin{array}{l}\text { We offer a doctoral practicum in college } \\
\text { teaching. We also offer doctoral } \\
\text { students the opportunity to teach } \\
\text { selected undergraduate and graduate } \\
\text { courses as adjuncts once they have } \\
\text { completed the college teaching } \\
\text { practicum. The students who teach as } \\
\text { adjuncts are assigned a mentor } \\
\text { (experienced, full-time faculty member) } \\
\text { to oversee their work in the course(s). }\end{array}$ \\
\hline
\end{tabular}




\begin{tabular}{|c|c|c|}
\hline 14 & No & $\begin{array}{l}\text { Doctoral students generally must } \\
\text { complete at least one "teaching } \\
\text { experience" which usually means } \\
\text { teaching a class under the guidance of } \\
\text { the regular class instructor. }\end{array}$ \\
\hline 15 & No & $\begin{array}{l}\text { By providing the students opportunities } \\
\text { to teach parts of courses and labs and to } \\
\text { develop, administer, and grade } \\
\text { assignments and tests in more than two } \\
\text { areas of student's interest. }\end{array}$ \\
\hline 16 & No & $\begin{array}{l}\text { Students can take courses on teaching. } \\
\text { We have also developed a new course } \\
\text { within the department on teaching at the } \\
\text { college level. Our students do have to } \\
\text { have at least one teaching experience in } \\
\text { the program - and we have developed an } \\
\text { annual review, which is a time where the } \\
\text { experience and feedback can be } \\
\text { discussed with the students. } \\
\text { We have discussed the possibility of } \\
\text { making some kind of teaching course a } \\
\text { requirement, but that is in the beginning } \\
\text { stages at this time. }\end{array}$ \\
\hline 17 & No & $\begin{array}{l}\text { Students spend one semester preparing } \\
\text { class with a PhD faculty advisor. The } \\
\text { next semester they teach the course } \\
\text { under the supervision of the same } \mathrm{PhD} \\
\text { faculty advisor. This is repeated as many } \\
\text { times as possible. }\end{array}$ \\
\hline 18 & No & $\begin{array}{l}\text { Teaching practica, and some get } \mathrm{TA} \\
\text { positions }\end{array}$ \\
\hline 19 & No & $\begin{array}{l}\text { The department offers an option for } \\
\text { faculty mentors who want to offer a } \\
\text { mentored teaching experience to their } \\
\text { PhD students Many faculty are } \\
\text { committed to providing scholarship of } \\
\text { teaching opportunities but some doctoral } \\
\text { students are heading for industry rather } \\
\text { than academic jobs and those faculty } \\
\text { mentors have other priorities. The } \\
\text { University Center for Excellence and } \\
\text { Innovation in Teaching has specialized } \\
\text { training for doctoral students and new } \\
\text { faculty. Also there are courses offered by } \\
\text { our health profession colleagues that }\end{array}$ \\
\hline
\end{tabular}


SMITH-OLINDE and Ellis: Pedagogy Education in CSD PhD Programs

\begin{tabular}{|l|l|l|}
\hline & $\begin{array}{l}\text { welcome our doctoral students who are } \\
\text { interested in this area. }\end{array}$ \\
\hline
\end{tabular}

